\title{
Can Different Salt Formulations Revert the Depressing Effect of Salinity on Maize by Modulating Plant Biochemical Attributes and Activating Stress Regulators through Improved N Supply?
}

\author{
Syed Ayyaz Javed ${ }^{1}$, Muhammad Saleem Arif 2,*(D), Sher Muhammad Shahzad 1,*(D), Muhammad Ashraf ${ }^{3}$, \\ Rizwana Kausar ${ }^{4}$, Taimoor Hassan Farooq ${ }^{5}{ }^{(\mathbb{D}}$, M. Iftikhar Hussain $^{6}{ }^{(b)}$ and Awais Shakoor ${ }^{7}$ \\ 1 Department of Soil and Environmental Sciences, College of Agriculture, University of Sargodha, \\ Sargodha 40100, Pakistan; ayazleo46@yahoo.com \\ 2 Department of Environmental Sciences and Engineering, GC University, Faisalabad 38000, Pakistan \\ 3 Department of Soil Science, Bahauddin Zakariya University, Multan 60800, Pakistan; \\ mashraf_1972@yahoo.com \\ 4 Soil and Water Testing Laboratory for Research, Sargodha 40100, Pakistan; amiq_14@yahoo.com \\ 5 Bangor College China, a Joint Unit of Bangor University, Wales, UK and Central South University of Forestry \\ and Technology, Changsha 410004, China; taimoorhassan2055@gmail.com \\ 6 Department of Plant Biology and Soil Science, University of Vigo, 36310 Vigo, Spain; mih786@gmail.com \\ 7 Department of Environment and Soil Sciences, University of Lleida, Avinguda Alcalde Rovira Roure 191, \\ 25198 Lleida, Spain; awais.shakoor@udl.cat \\ * Correspondence: msarif@outlook.com (M.S.A.); smshahzad_pk@yahoo.com (S.M.S.)
}

Citation: Javed, S.A.; Arif, M.S.; Shahzad, S.M.; Ashraf, M.; Kausar, R.; Farooq, T.H.; Hussain, M.I.; Shakoor, A. Can Different Salt Formulations Revert the Depressing Effect of Salinity on Maize by Modulating Plant Biochemical Attributes and Activating Stress Regulators through Improved N Supply? Sustainability 2021, 13, 8022. https://doi.org/ $10.3390 /$ su13148022

Academic Editor: Jeroen Meersmans

Received: 12 June 2021

Accepted: 13 July 2021

Published: 19 July 2021

Publisher's Note: MDPI stays neutral with regard to jurisdictional claims in published maps and institutional affiliations.

Copyright: (c) 2021 by the authors. Licensee MDPI, Basel, Switzerland. This article is an open access article distributed under the terms and conditions of the Creative Commons Attribution (CC BY) license (https:// creativecommons.org/licenses/by/ $4.0 /)$.
Abstract: Salinity is a major constraint in improving agricultural productivity due to its adverse impact on various physiological and biochemical attributes of plants, and its effect on reducing nitrogen $(\mathrm{N})$ use efficiency due to ion toxicity. To understand the relationship between sodium chloride $(\mathrm{NaCl})$ and increased $\mathrm{N}$ application rates, a pot study was performed in which the ammonical $\left(\mathrm{NH}_{4}{ }^{+}\right)$form of $\mathrm{N}$ was applied as urea to maize crops at different rates (control, 160, 186, 240, 267, 293, and $320 \mathrm{~kg} \mathrm{~N} \mathrm{ha}^{-1}$ ) using two salinity levels (control and $10 \mathrm{dS} \mathrm{m}^{-1} \mathrm{NaCl}$ ). The results indicate that all biochemical and physiological attributes of the maize plant improved with increased concentration of $\mathrm{N}$ up to $293 \mathrm{~kg} \mathrm{ha}^{-1}$, compared to those in the control treatment. Similarly, the optimal N concentration regulated the activities of antioxidant enzymes, i.e., catalase activity (CAT), peroxidase activity (POD), and superoxide dismutases (SOD), and also increased the $\mathrm{N}$ use efficiencies of the maize crop up to $293 \mathrm{~kg} \mathrm{~N}$ ha $^{-1}$. Overall, our results show that the optimum level of $\mathrm{N}\left(293 \mathrm{~kg} \mathrm{ha}^{-1}\right)$ improved the salinity tolerance in the maize plant by activating stress coping physiological and biochemical mechanisms. This may have been due to the major role of $\mathrm{N}$ in the metabolic activity of plants and $\mathrm{N}$ assimilation enzymes activity such as nitrate reductase (NR) and nitrite reductase (NiR).

Keywords: sodium chloride; nitrogen levels; biochemical attributes; antioxidant enzymes; nitrogen use efficiencies; maize

\section{Introduction}

Salinity is a major environmental limitation, causing extensive crop losses worldwide [1]. The increase in salinity has reduced the average yield of field crops by more than $50 \%$, and these losses are of great concern, especially for agricultural countries [2]. Among abiotic stresses, salinity has an eminent position in reducing yield and quality by showing its damaging impact on global sustainable agriculture [3,4]. Salinization is increasing daily due to climate change and the poor quality of irrigation water [2,3]. Under the root zone of plants, a harmful condition is created by the high concentration of soluble salts such as sodium chloride $(\mathrm{NaCl})$, which ultimately contribute to the inhibition of biochemical and physiological processes in plants, reducing their growth, quality, and productivity [5]. Based on their ability to survive under a saline environment, two types 
of plants are distinguished, glycophytes and halophytes. Halophytes (e.g., smooth cordgrass and pickleweed) can tolerate high salinity due to compartmentalization, osmolyte production, and compatible solutes, while, glycophytes (e.g., rice, sunflower, sugar beets, and maize) cannot tolerate high salinity at both the cellular and plant level [6]. Most of the terrestrial plant population are glycophytes including field crops [3,7]. High salinity causes many physical and metabolic alterations such as osmotic stress, specific ion toxicity and ion imbalance, and production of reactive oxygen species (ROS), and these changes lead to decreased plant growth and productivity $[3,8]$. The osmotic effect is also known as the rapid effect because the accumulation of soluble salts under the root zone, reduces the ability of plants to absorb water, disturbing the stability index of the membranes and causing plant death. Similarly, ion toxicity and nutrient imbalance are secondary or later effects because of the accumulation and distribution of soluble salts within plant bodies in high concentrations [9]. A close relationship has been observed between soluble salts and essential plant nutrients, for example, sodium $\left(\mathrm{Na}^{+}\right)$interacts with calcium $\left(\mathrm{Ca}^{2+}\right)$, potassium $\left(\mathrm{K}^{+}\right)$, magnesium $\left(\mathrm{Mg}^{2+}\right)$, and ammonium $\left(\mathrm{NH}_{4}^{+}\right)$, while, chloride $\left(\mathrm{Cl}^{-}\right)$interacts with sulfate $\left(\mathrm{SO}_{4}{ }^{2-}\right)$ and nitrate $\left(\mathrm{NO}_{3}{ }^{-}\right)$ions [10]. These interactions under high salinity disrupt ion uptake, causing plants to become nutrient-deficient, and eventually lead to poor plant yield and quality. Salt accumulation also destabilizes the stomatal opening of plant leaves, disrupting the influx and efflux ratios of carbon dioxide $\left(\mathrm{CO}_{2}\right)$ and oxygen $\left(\mathrm{O}_{2}\right)$ and restricting the fixation of $\mathrm{CO}_{2}$ in plants [11]. The exchange of gases within plants inversely relates to the concentration of $\mathrm{Na}^{+}$and $\mathrm{Cl}^{-}$ions and other plant attributes such as transpiration, the conductance of stomata, and photosynthetic processes, adversely affected by a saline environment $[12,13]$. In the same way as under saline conditions, plants produce compatible solutes such as sugar alcohols and proline content in order to scavenge ROS. These compatible solutes are hydrophilic in nature [11].

Among plant essential nutrients, $\mathrm{N}$ is considered to be one of the dominant nutrient abundantly absorbed by plants because it is a major component of numerous compounds synthesized within the plant body, such as proteins, amino acids, polyamides, and quaternary ammonium compounds involved in protection of plants under stress conditions; however, high salinity causes a reduction in $\mathrm{N}$ uptake and deregulates all functions mediated by $\mathrm{N}$ uptake [14]. For instance, $\mathrm{N}$ uptake under salinity is reduced due to the antagonistic effect of $\mathrm{N}$ forms (i.e., $\mathrm{NO}_{3}{ }^{-}$and $\mathrm{NH}_{4}{ }^{+}$) with salt ions. In Pakistani soils, $\mathrm{Na}^{+}$and $\mathrm{Cl}^{-}$ions are more dominant, and soluble ions are due to alkaline calcareous soils. Sodium ions compete with $\mathrm{NH}_{4}{ }^{+}$, and $\mathrm{Cl}^{-}$ions compete with the $\mathrm{NO}_{3}{ }^{-}$form of $\mathrm{N}$, which causes a reduction in $\mathrm{N}$ uptake [15]. Therefore, the optimal supply of $\mathrm{N}$ under a saline environment could be a significant strategy to combat the negative effects of salinity and obtain optimal productivity from saline soils. Various studies have evaluated the relationship between $\mathrm{N}$ nutrition and plant growth responses in salt-affected soils, with increased salinization, shortage of good-quality irrigation water, and overpopulation are imposing major threat to food security [16-18]. Adequate $\mathrm{N}$ application under salt-affected soils can minimize the deleterious effects of salinity to plant growth and development by regulating osmotic stress [19], improving antioxidant activities [20], increasing stomatal conductance [21], mitigating ion toxicity [22], and improving photosynthetic processes [23], and by triggering the activities of $\mathrm{N}$ assimilation enzymes such as nitrate reductase (NR) and nitrite reductase (NiR) [24], and improving $\mathrm{N}$ use efficiency [25].

Similarly, an adequate supply of $\mathrm{N}$ under a saline environment also improves the plant biomass and root system. Due to the proliferation of plant roots, nutrient and water uptake increases, which subsequently improves the ability of plants to survive under stress conditions [26]. An adequate level of $\mathrm{N}$ also adjusts the selectivity of plant roots for nutrient uptake and increases the exclusion ability of salt ions through leaves to improve the tolerance capacity of plants under salt stress $[27,28]$. All these improvements in plant growth and development through higher $\mathrm{N}$ application under salt-affected soils improve the tolerance ability of plants, leading to a sustainable yield of field crops. 
By keeping in view all these improvements of $\mathrm{N}$ nutrition in plants under salinity stress, we conducted an experiment using maize as a test crop because maize is the third staple crop after wheat and rice in Pakistan, and it is moderately sensitive to salinity. Specifically, we evaluated the interactive effect of salinity and different $\mathrm{N}$ application rates to determine the best $\mathrm{N}$ level for maize crops under salt stress.

\section{Materials and Methods}

\subsection{Experimental Site}

A pot study was conducted to evaluate the relation between different nitrogen rates and salinity stress on physiological and biochemical attributes of the maize plant in wire house conditions at the research area, College of Agriculture, University of Sargodha, Sargodha (latitude $32.082^{\circ} \mathrm{N}$, longitude $72,669^{\circ}$ E, and altitude $190 \mathrm{~m}$ ) Punjab, Pakistan, during 2016.

\subsection{Pot Experiment}

A pot study was performed for optimization of $\mathrm{N}$ application rates at two different salinity levels. The study comprised a $(7 \times 2)$ factorial completely randomized design (CRD), with four repeats per treatment. The experiment had seven different $\mathrm{N}$ levels (control, 160, 186, 240, 267, 293, and $320 \mathrm{~kg} \mathrm{ha}^{-1}$ ) and two different salinity levels (control, $\left.10 \mathrm{dS} \mathrm{m}^{-1}\right)$.

Sandy clay loam soil was used in this study, which belongs to the Lyallpur soil series (Aridisols fine silty, hyperthermic haplic vermosols according to FAO Soil Classification System), and it was collected from the fields of the College of Agriculture, University of Sargodha, Sargodha. Ten different soil samples from a depth of $0-15 \mathrm{~cm}$ were collected and hand sorted to remove any visible stones in the field and complete/intact dead and/or live vegetation before they were thoroughly mixed to develop a composite soil sample. The composite soil sample was air dried, then sieved through a $2 \mathrm{~mm}$ mesh screen, and analyzed for physicochemical and biochemical properties (Table 1).

Table 1. Physicochemical properties of soil to be used for experiments of this study.

\begin{tabular}{ccc}
\hline Soil Properties & Value & References \\
\hline Physical properties & & \\
Sand $\left(\mathrm{g} \mathrm{kg}^{-1}\right)$ & 581.0 & \\
Silt $\left(\mathrm{g} \mathrm{kg}^{-1}\right)$ & 293.0 & Bouyoucos [29] \\
Clay $\left(\mathrm{g} \mathrm{kg}^{-1}\right)$ & 126.0 & \\
Textural class & Sandy clay loam & \\
Saturation percentage & 34 & \\
Chemical properties & & \\
pH & $7.85 \pm 0.06$ & Jackson [30] \\
Electrical conductivity $(\mu \mathrm{S} \mathrm{cm}$ & \\
Organic matter $\left(\mathrm{g} \mathrm{kg}^{-1}\right)$ & $9.97 \pm 1.14$ & Walkley and Black [31] \\
Total organic C $\left(\mathrm{g} \mathrm{kg}^{-1}\right)$ & $5.87 \pm 0.31$ & \\
Dissolved organic C $\left(\mathrm{mg} \mathrm{kg}^{-1}\right)$ & $45.90 \pm 4.65$ & Bremner and Tabatabai [32] \\
Total N $\left(\mathrm{mg} \mathrm{kg}^{-1}\right)$ & $264.04 \pm 9.40$ & Olsen et al. [33] \\
Available P $\left(\mathrm{mg} \mathrm{kg}^{-1}\right)$ & $8.94 \pm 0.67$ & Hanway and Heidel [34] \\
Available K $\left(\mathrm{mg} \mathrm{kg}^{-1}\right)$ & $189.4 \pm 9.42$ &
\end{tabular}

After this, pots were filled with $15 \mathrm{~kg}$ soil that had dimensions of $36 \times 54 \mathrm{~cm}$, and salinity levels were developed at the time of soil filling. The recommended dose of chemical (PK) fertilizers at 80:60 $\mathrm{kg} \mathrm{ha}^{-1}$ was applied as diammonium phosphate (DAP) and sulphate of potash (SOP) in all treatments at the time of filling and mixing of soil in pots, while different levels of $\mathrm{N}$ (control, 160, 186, 240, 267, 293, and $320 \mathrm{~kg} \mathrm{ha}^{-1}$ ) as urea were applied to select the most effective level of $\mathrm{N}$ at salinity of $\mathrm{EC} 10 \mathrm{dS} \mathrm{m}^{-1}$ using salt $(\mathrm{NaCl})$ under pot conditions. However, a full dose of $\mathrm{P}$ and $\mathrm{K}$ fertilizers was applied as a basal dose at the time of soil filling, one third $(1 / 3 \mathrm{rd})$ of the recommended dose of $\mathrm{N}$ was applied at the 
time sowing, and the remaining quantity of $\mathrm{N}$ was top dressed into three equal splits at different growth stages of maize plants.

Then, each pot was irrigated with water to develop optimal moisture conditions $(70 \%$ WHC (water holding capacity)) for sowing. Four seeds of hybrid maize (cv. FH-1046, Pioneer Pakistan Seed Ltd.) per pot were sown, and only one plant was maintained in each pot for further development. After 15 days of germination, the uprooted plants were incorporated in the soil of the same pot. Good-quality irrigation water was applied throughout the research that had EC $0.075 \mathrm{dS} \mathrm{m}^{-1}$, SAR $0.34\left(\mathrm{mmol} \mathrm{L}^{-1}\right)^{1 / 2}$, and zero RSC. In addition, all agronomic practices were used to overcome crop diseases and weeds during the study.

All the biochemical parameters including chlorophyll contents ( $a, b$, and total), leaf area, relative water content, membrane stability index, electrolyte leakage, photosynthetic $\mathrm{N}$ use efficiency, proline content, carotenoid content, malondialdehyde content, catalase activity, peroxidase activity, superoxide dismutase activity, $\mathrm{N}$ harvest index, $\mathrm{N}$ use efficiency, $\mathrm{N}$ yield efficiency, and physiological $\mathrm{N}$ efficiency were determined after the harvest of crops using standard procedures. After harvesting, the physicochemical and biochemical analyses of soils were performed in the laboratory.

\subsection{Soil Analysis}

Soil samples were collected at the depth of $0-30 \mathrm{~cm}$ from the research area in order to measure the physicochemical properties of the soil. For the determination of soil texture, the hydrometer method was used [29]. Finally, a textural triangle was used to find the textural class of the soil [35]. Soil pH was determined by using a pH meter (JENWAY-3510). For this, a suspension ratio of soil and water (1:5) was prepared to analyze the $\mathrm{pH}$ of the soil. Electrical conductivity (EC) of soil was measured using the conductivity bridge method explained by Jackson [30], while the soil saturation percentage was determined by using a prescribed formula. A fraction of soil saturated paste was oven dried at $105^{\circ} \mathrm{C}$ to a constant weight. Then, the saturation percentage was determined by using the following formula.

$$
\text { Water content }(\%)=\frac{\text { Loss in weight on drying }}{\text { Oven dry weight of soil }} \times 100
$$

For the determination of $\mathrm{N}$ from the soil, two steps are involved (digestion and distillation) in the estimation of total $\mathrm{N}$ from the soil using Kjeldhal's distillation apparatus [32]. Total organic $\mathrm{C}$ content in the soil was determined by using dichromate oxidation followed by titration with acidified ferrous ammonium sulphate $\left(\mathrm{FeH}_{8} \mathrm{~N}_{2} \mathrm{O}_{8} \mathrm{~S}_{2}\right)$ using a modified Walkley and Black method [31], while dissolved organic C (DOC) of the sampled soil was extracted with distilled water (1:5 w/v ratio), and the amount of the $C$ concentration was determined as described by Walkley and Black [31].

Soil available phosphorus was estimated by the sodium bicarbonate $\left(\mathrm{NaHCO}_{3}\right)$ extraction method [33]. For this, $3.0 \mathrm{~g}$ air-dried soil was properly mixed with $0.5 \mathrm{M} \mathrm{NaHCO}_{3}$ $(60 \mathrm{~mL})$ into a $150 \mathrm{~mL}$ Erlenmeyer flask followed by shaking at $150 \mathrm{rpm}$ for $30 \mathrm{~min}$. The amount of available $P$ in the filtrate was determined spectrophotometrically $(\lambda=880 \mathrm{~nm})$ using ascorbate-molybdate reagent [33]. Soil available $\mathrm{K}$ was measured using the ammonium acetate $\left(\mathrm{CH}_{3} \mathrm{COO}-\mathrm{NH}_{4}\right)$ extraction method [34]. For this, $5.0 \mathrm{~g}$ air-dried soil in $50 \mathrm{~mL}$ of $1 \mathrm{M} \mathrm{CH}_{3} \mathrm{COO}-\mathrm{NH}_{4}$ solution ( $\mathrm{pH}$ 7) was shaken for $30 \mathrm{~min}$ at $275 \mathrm{rpm}$. The soil solution suspension was allowed to settle, and the extract was filtered through Whatman No. 2. The available $\mathrm{K}$ concentration in the soil extract was determined by flame spectrometry (Flame photometer PFP7).

\subsection{Plant Analysis}

Different physiological parameters (i.e., relative water content, membrane stability index, electrolyte leakage, chlorophyll contents (a, b, and total), carotenoid content, nitrogen use efficiency (NUE), nitrogen yield efficiency (NYE), physiological nitrogen efficiency (PNE), photosynthetic $\mathrm{N}$ use efficiency (PNUE), and $\mathrm{N}$ harvest index (NHI)) were taken 
after 45 days of treatments application. In the case of biochemical attributes, proline content, and antioxidant enzymes were determined after 60 days of germination.

The percentage of relative water content (RWC) was determined according to the technique of Turner [36] using following formula.

$$
\text { RWC }(\%)=\frac{\text { Fresh weight }- \text { Dry weight }}{\text { Turgid weight }- \text { Dry weight }} \times 100
$$

The electrolyte leakage (EL) percentage was found according to the procedure described by Lutts et al. [37] and estimated according to the following equation.

$$
\mathrm{EL}(\%)=\frac{\mathrm{EC} 1}{\mathrm{EC} 2} \times 100
$$

The membrane stability index (MSI) percentage was determined according to the equation given by Singh et al. [38].

$$
\text { MSI }(\%)=\frac{1-\mathrm{EC} 1}{\mathrm{EC} 2} \times 100
$$

Chlorophyll and carotenoid contents were analyzed according to the methods explained by Shabala et al. [39] and Lichtenthaler [40], respectively. The leaf area of plants was calculated using a leaf area meter (CI-202). Proline content was determined using the method described by Bates et al. [41] with a spectrophotometer at a $528 \mathrm{~nm}$ wavelength. Malondialdehyde (MDA) concentration was spectrophotometrically determined from leaf samples at a wavelength of $532 \mathrm{~nm}$ [42].

\subsection{Determination of Antioxidant Enzymatic Activities}

For this, a leaf sample was arranged according to method elucidated by Mukherjee and Choudhuri [43]. Catalase activity (CAT) was examined via a reaction solution of $50 \mathrm{mM}$ phosphate buffer, $\mathrm{H}_{2} \mathrm{O}_{2}(30 \%)$, and $0.5 \mathrm{~mL}$ solution of enzymatic extract [44]. For the determination of peroxidase (POD) activity, the method of Maehly and Chance [45] was used. For this, guaiacol was oxidized in the presence of hydrogen peroxide $\left(\mathrm{H}_{2} \mathrm{O}_{2}\right)$, while the activity of superoxide dismutase (SOD) was estimated by the technique illustrated by Dhindsa et al. [46].

\subsection{Nitrogen Harvest Index}

The ratio of nitrogen uptake by seeds to total plant biomass is known as the nitrogen harvest index [47]. It is determined by the following equation.

$$
\mathrm{NHI}=\frac{\mathrm{NY}}{\mathrm{NYt}}
$$

where $\mathrm{NY}=$ nitrogen uptake by seeds, and NYt = nitrogen taken up by total plant biomass

\subsection{Nitrogen Use Efficiency}

Nitrogen use efficiency (NUE) was predicted by applying the following equation [48].

$$
\mathrm{NUE}=\frac{\mathrm{N}_{\mathrm{ui}}-\mathrm{N}_{\mathrm{uc}}}{\mathrm{N}_{\mathrm{fi}}-\mathrm{N}_{\mathrm{fc}}}
$$

where $\mathrm{N}_{\mathrm{ui}}$ and $\mathrm{N}_{\mathrm{uc}}=$ nitrogen uptake by seeds and straw in various treatments and control, and $\mathrm{N}_{\mathrm{fi}}$ and $\mathrm{N}_{\mathrm{fc}}=$ nitrogen in the form of fertilizers in various treatments and control. 


\subsection{Nitrogen Yield Efficiency}

Nitrogen yield efficiency (NYE) was estimated to find the inputs of nitrogen utilization in response to nitrogen application [49]. It can be calculated using the formula

$$
N Y E=\frac{Y_{i}-Y_{c}}{N_{f i}-N_{f c}}
$$

where $Y_{i}=$ nitrogen in seed yield in various treatments, and $Y_{c}=$ nitrogen in control treatment. For the calculation of NYE, the amount of nitrogen applied and the yield of seeds should be determined.

\subsection{Physiological Nitrogen Efficiency}

Physiological nitrogen efficiency (PNE) was also calculated, by using the following equation [50].

$$
\mathrm{PNE}=\frac{\mathrm{Y}_{\mathrm{i}}-\mathrm{Y}_{\mathrm{c}}}{\mathrm{N}_{\mathrm{ui}}-\mathrm{N}_{\mathrm{uc}}}
$$

where $\mathrm{N}_{\mathrm{ui}}$ and $\mathrm{N}_{\mathrm{uc}}=$ nitrogen uptake by seeds and straw in various treatments and control, respectively.

\subsection{Photosynthetic Nitrogen Use Efficiency}

Photosynthetic nitrogen use efficiency can be determined from the readings of the photosynthetic rate and leaves' $\mathrm{N}$ content using the formula described by Poorter and Evans [51].

$$
\mathrm{PNUE}=\frac{\mathrm{RPL}}{\mathrm{SNL}}
$$

where RPL $=$ rate of photosynthesis in leaf $\left(\mathrm{mmol} \mathrm{m}^{-2} \mathrm{~s}^{-1}\right)$, and $\mathrm{SNL}=$ specific $\mathrm{N}$ content in leaf $\left(\mathrm{g} \mathrm{m}^{-2}\right)$. Overall, the PNUE is described in the unit of $\mu \mathrm{mol} \mathrm{g}^{-1} \mathrm{~s}^{-1}$.

\subsection{Statistical Analysis}

The data were analyzed using the Statistix 10 statistical package [52], and to compare the difference among the treatment means, we used the least significant difference (LSD) test at $0.05 \mathrm{P}$ [53].

\section{Results}

In this study, seven different $\mathrm{N}$ levels (control, 160, 186, 240, 267, 293, and $320 \mathrm{~kg} \mathrm{~N} \mathrm{ha}^{-1}$ ) were tested to evaluate the optimum $\mathrm{N}$ application rate for the physiological and biochemical attributes of maize, as well as different $\mathrm{N}$ use efficiencies under saline conditions.

\subsection{Physiological Stress Indicators of Plants}

The results of the relative water content (RWC) show that the RWC in the plants was significantly affected by all salt levels (SL), nitrogen levels (NL), and their interaction in the two-way ANOVA test (Table 2). In the control treatment, an increase in the RWC was observed with an increase in the $\mathrm{N}$ concentration. The highest RWC appeared at the N5 level, which was $70.57 \%$, and a low RWC (59.68\%) was observed in N0 (control) at a salinity level of $10 \mathrm{dS} \mathrm{m}^{-1}$, while N1, N2, and N3 showed nonsignificant results across the control pots. 
Table 2. Effect of different $\mathrm{N}$ application rates on physiological stress indicators of maize plants under salt stress in pot conditions.

\begin{tabular}{|c|c|c|c|c|c|c|c|c|c|c|}
\hline \multirow[t]{2}{*}{ Nitrogen Levels } & \multicolumn{2}{|c|}{$\begin{array}{c}\text { Relative Water Content } \\
(\%)\end{array}$} & \multicolumn{2}{|c|}{$\begin{array}{c}\text { Membrane Stability Index } \\
(\%)\end{array}$} & \multicolumn{2}{|c|}{$\begin{array}{c}\text { Electrolyte Leakage } \\
(\%)\end{array}$} & \multicolumn{2}{|c|}{$\begin{array}{l}\text { Proline Content } \\
\left(\mu \mathrm{mol} \mathrm{g}^{-1} \mathrm{DW}\right)\end{array}$} & \multicolumn{2}{|c|}{$\begin{array}{c}\text { Malondialdehyde Content } \\
\left(\mathrm{mg} \mathrm{g}^{-1}\right)\end{array}$} \\
\hline & Control & $10 \mathrm{dS} \mathrm{m}^{-1}$ & Control & $10 \mathrm{dS} \mathrm{m}^{-1}$ & Control & $10 \mathrm{dS} \mathrm{m}^{-1}$ & Control & $10 \mathrm{dS} \mathrm{m}^{-1}$ & Control & $10 \mathrm{dS} \mathrm{m}^{-1}$ \\
\hline $\begin{array}{l}\text { N0: control } \\
\text { (untreated) }\end{array}$ & $74.41 \mathrm{c}$ & $59.68 \mathrm{f}$ & $33.37 \mathrm{~d}$ & $17.65 \mathrm{~h}$ & $66.63 \mathrm{~d}$ & $82.35 \mathrm{a}$ & $4.25 \mathrm{~d}$ & $12.11 \mathrm{a}$ & $19.11 \mathrm{e}$ & $37.49 \mathrm{a}$ \\
\hline $\mathrm{N} 1: 160 \mathrm{~kg} \mathrm{ha}^{-1}$ & $75.53 \mathrm{bc}$ & 62.55 ef & $33.51 \mathrm{~cd}$ & $19.41 \mathrm{fg}$ & $66.49 \mathrm{~d}$ & $80.59 \mathrm{ab}$ & $4.02 \mathrm{~d}$ & $11.39 \mathrm{a}$ & 17.73 ef & $35.81 \mathrm{abc}$ \\
\hline $\mathrm{N} 2: 186 \mathrm{~kg} \mathrm{ha}^{-1}$ & $77.01 \mathrm{abc}$ & $62.63 \mathrm{ef}$ & $34.28 \mathrm{bcd}$ & $20.27 \mathrm{f}$ & $65.72 \mathrm{~d}$ & $79.73 \mathrm{ab}$ & $4.08 \mathrm{~d}$ & $11.72 \mathrm{a}$ & $17.64 \mathrm{ef}$ & $35.15 \mathrm{bc}$ \\
\hline N3: $220 \mathrm{~kg} \mathrm{ha}^{-1}$ & $77.39 \mathrm{abc}$ & $63.61 \mathrm{e}$ & $34.35 \mathrm{abc}$ & $20.29 \mathrm{f}$ & $65.65 \mathrm{~d}$ & $79.71 \mathrm{ab}$ & $3.97 \mathrm{~d}$ & $11.65 \mathrm{a}$ & $17.40 \mathrm{efg}$ & $35.71 \mathrm{abc}$ \\
\hline $\mathrm{N} 4: 267 \mathrm{~kg} \mathrm{ha}^{-1}$ & $78.07 \mathrm{ab}$ & $68.66 \mathrm{~d}$ & $35.55 \mathrm{ab}$ & $23.44 \mathrm{e}$ & $64.45 \mathrm{~d}$ & $76.56 \mathrm{bc}$ & $3.92 \mathrm{~d}$ & $10.27 \mathrm{~b}$ & $16.05 \mathrm{fg}$ & $34.07 \mathrm{~cd}$ \\
\hline N5: $293 \mathrm{~kg} \mathrm{ha}^{-1}$ & $79.15 \mathrm{a}$ & $70.57 \mathrm{~d}$ & $36.81 \mathrm{a}$ & $26.04 \mathrm{e}$ & $63.19 \mathrm{~d}$ & $73.96 \mathrm{c}$ & $3.86 \mathrm{~d}$ & $8.90 \mathrm{c}$ & $15.44 \mathrm{~g}$ & $32.38 \mathrm{~d}$ \\
\hline \multirow[t]{2}{*}{ N6: $320 \mathrm{~kg} \mathrm{ha}^{-1}$} & $74.47 \mathrm{c}$ & $61.14 \mathrm{ef}$ & $33.18 \mathrm{~cd}$ & $16.86 \mathrm{gh}$ & $66.82 \mathrm{~d}$ & $83.14 \mathrm{a}$ & $4.17 \mathrm{~d}$ & $11.83 \mathrm{a}$ & $18.09 \mathrm{ef}$ & $36.53 \mathrm{ab}$ \\
\hline & \multicolumn{10}{|c|}{ Interactions between salinity levels and nitrogen levels } \\
\hline SL & \multicolumn{2}{|c|}{$342.77^{* * *}$} & \multicolumn{2}{|c|}{$908.86^{* * *}$} & \multicolumn{2}{|c|}{$219.37^{* * *}$} & \multicolumn{2}{|c|}{$1779.17^{* * *}$} & \multicolumn{2}{|c|}{$1923.38^{* * *}$} \\
\hline NL & \multicolumn{2}{|c|}{$10.24^{* * *}$} & \multicolumn{2}{|c|}{$16.34^{* * *}$} & \multicolumn{2}{|c|}{$3.20 *$} & \multicolumn{2}{|c|}{$8.05^{* * *}$} & \multicolumn{2}{|c|}{$7.18^{* * *}$} \\
\hline $\mathrm{SL} \times \mathrm{NL}$ & \multicolumn{2}{|c|}{1.94 * } & \multicolumn{2}{|c|}{$2.38 *$} & \multicolumn{2}{|c|}{$0.73 \mathrm{~ns}$} & \multicolumn{2}{|c|}{$5.37 * * *$} & \multicolumn{2}{|c|}{$0.22 \mathrm{~ns}$} \\
\hline $\mathrm{CV}$ & \multicolumn{2}{|c|}{3.58} & \multicolumn{2}{|c|}{8.33} & \multicolumn{2}{|c|}{4.83} & \multicolumn{2}{|c|}{8.29} & \multicolumn{2}{|c|}{5.82} \\
\hline
\end{tabular}

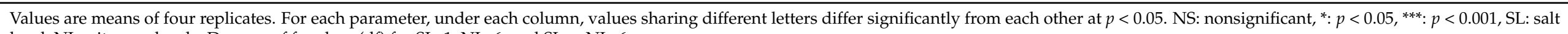
level, NL: nitrogen levels. Degrees of freedom (df) for SL: 1, NL: 6, and SL $\times$ NL: 6 . 
The data regarding the membrane stability index (MSI) demonstrate that SL, NL, and their interaction affected the MSI markedly (Table 2). All treatments showed a significant difference among each other over the untreated control (N0). In control pots, and at $10 \mathrm{dS} \mathrm{m}^{-1}$ salinity, all treatments had an increased MSI with an increase in the $\mathrm{N}$ level, except for the $\mathrm{N} 6$ level $\left(320 \mathrm{~kg} \mathrm{~N}\right.$ ha $\left.{ }^{-1}\right)$. The highest MSI at $10 \mathrm{dS} \mathrm{m}^{-1}$ was recorded as $26.01 \%$ as a result of the N5 level $\left(293 \mathrm{~kg} \mathrm{~N} \mathrm{ha}^{-1}\right)$, while the lowest MSI (up to $17.65 \%$ ) was obtained in the untreated control (N0).

In the case of electrolyte leakage (EL), both SL and NL depicted a significant effect on the EL content; however, their interaction $(S L \times N L)$ effect was found to be nonsignificant (Table 2). Across the control pots, no considerable differences in EL were recorded between the N0 and N6 treatments. In the case of the $10 \mathrm{dS} \mathrm{m}{ }^{-1}$ level of salinity, the N5 treatment was able to induce a significant reduction in EL of $73.96 \%$, as compared to the untreated control (N0) treatment.

The data regarding the proline content reveal that both SL and NL depicted a significant effect on the proline content, while their interaction was also found to be significant (Table 2). In the case of the control, no considerable differences in the proline content were recorded between the N0 and N6 treatments. Meanwhile, in the case of $10 \mathrm{dS} \mathrm{m} \mathrm{m}^{-1}$ salinity, the $\mathrm{N} 5\left(293 \mathrm{~kg} \mathrm{~N} \mathrm{ha}^{-1}\right)$ treatment was able to induce a significant decrease in the proline content of up to $8.90 \mu \mathrm{mol} \mathrm{g}{ }^{-1} \mathrm{DW}$, as compared to the untreated control treatment (N0).

Both SL and NL showed a significant effect on the malondialdehyde (MDA) content; however, their interaction effect was found to be nonsignificant in this experiment (Table 2). Across the control pots, a considerable difference in the MDA content was recorded between the N0 and N6 treatments. In the case of the control and $10 \mathrm{dS} \mathrm{m}^{-1}$ salinity, the N5 treatment was able to induce a significant reduction in the MDA content $\left(32.38 \mathrm{mg} \mathrm{g}^{-1}\right)$, as compared to the N0 treatment, whereas a high value of the MDA content was recorded up to $19.11 \mathrm{mg} \mathrm{g}^{-1}$ as a result of the N0 (control) treatment.

\subsection{Leaf Area and Physiological Attributes of Maize Plants}

The leaf area of maize plants indicated that SL, NL, and the interaction of both SL $\times$ NL affected the leaf area significantly (Table 3). All $\mathrm{N}$ levels increased the leaf area of maize plants markedly in normal and salinity-formulated soils at $10 \mathrm{dS} \mathrm{m}^{-1}$. The highest leaf areas of 436.42 and $374.86 \mathrm{~cm}^{2}$ of maize plants were recorded due to application of the N5 treatment in normal and salinity-formulated soils at $10 \mathrm{dS} \mathrm{m}^{-1}$, respectively.

The results regarding the chlorophyll a content show that SL and NL affected the chlorophyll a content in maize plants significantly, but their interaction exhibited a nonsignificant impact on the chlorophyll $a$ content (Table 3). Across the control and $10 \mathrm{dS} \mathrm{m}^{-1}$ soil pots, a significant increase in the chlorophyll a content was recorded with an increase in N levels up to N5. Similarly, the chlorophyll b content in plant leaves revealed that SL and NL affected the chlorophyll b content in maize plants significantly, but a nonsignificant effect on the chlorophyll b content was found by their interaction (Table 3). Across the control and $10 \mathrm{dS} \mathrm{m} \mathrm{m}^{-1}$ soil pots, a significant increase in the chlorophyll b content was recorded due to an increase in $\mathrm{N}$ levels up to $\mathrm{N} 5\left(293 \mathrm{~kg} \mathrm{~N} \mathrm{ha}^{-1}\right)$, while the lowest value was observed at the N0 level of N. However, the results regarding the total chlorophyll content show that SL and NL affected the total chlorophyll content in maize plants significantly, but a nonsignificant effect was observed by their interaction (Table 3). In all control and $10 \mathrm{dS} \mathrm{m}^{-1}$ soil pots, a significant increase in the total chlorophyll content was recorded with an increase in $\mathrm{N}$ levels up to $\mathrm{N} 5\left(293 \mathrm{~kg} \mathrm{~N} \mathrm{ha}^{-1}\right)$, while the lowest chlorophyll content was observed in the untreated control (N0) treatment.

The salinity level (SL) and nitrogen level (NL) affected the carotenoid content significantly according to the ANOVA test of this parameter (Table 3). The interaction of both $\mathrm{SL} \times \mathrm{NL}$ showed a nonsignificant impact on the carotenoid content. A significant increase in the carotenoid content was observed in all treatments over the control (N0). The highest content of carotenoids was observed at the $\mathrm{N} 5\left(293 \mathrm{~kg} \mathrm{~N} \mathrm{ha}^{-1}\right)$ treatment in normal control pots and in pots at a salinity level of $10 \mathrm{dS} \mathrm{m} \mathrm{m}^{-1}$. 
Table 3. Effect of different $\mathrm{N}$ application rates on leaf area and physiological attributes of maize plants under salt stress in pot conditions.

\begin{tabular}{|c|c|c|c|c|c|c|c|c|c|c|}
\hline \multirow[t]{2}{*}{ Nitrogen Levels } & \multicolumn{2}{|c|}{ Leaf Area $\left(\mathrm{cm}^{2}\right)$} & \multicolumn{2}{|c|}{$\begin{array}{l}\text { Chlorophyll a Content } \\
\left(\mathrm{mg} \mathrm{g}^{-1}\right)\end{array}$} & \multicolumn{2}{|c|}{$\begin{array}{l}\text { Chlorophyll b Content } \\
\left(\mathrm{mg} \mathrm{g}^{-1}\right)\end{array}$} & \multicolumn{2}{|c|}{$\begin{array}{l}\text { Total Chlorophyll Content } \\
\left(\mathrm{mg} \mathrm{g}^{-1}\right)\end{array}$} & \multicolumn{2}{|c|}{$\begin{array}{l}\text { Carotenoid Content } \\
\left(\mathrm{mg} g-{ }^{1}\right)\end{array}$} \\
\hline & Control & $10 \mathrm{dS} \mathrm{m}^{-1}$ & Control & $10 \mathrm{dS} \mathrm{m}^{-1}$ & Control & $10 \mathrm{dS} \mathrm{m}^{-1}$ & Control & $10 \mathrm{dS} \mathrm{m}^{-1}$ & Control & $10 \mathrm{dS} \mathrm{m}^{-1}$ \\
\hline $\begin{array}{l}\text { N0: control } \\
\text { (untreated) }\end{array}$ & $361.11 \mathrm{f}$ & $286.10 \mathrm{i}$ & $1.95 \mathrm{c}$ & $1.23 \mathrm{~g}$ & $1.15 \mathrm{~d}$ & $0.73 \mathrm{~g}$ & $3.10 \mathrm{c}$ & $1.96 \mathrm{f}$ & $0.605 \mathrm{c}$ & $0.442 \mathrm{e}$ \\
\hline $\mathrm{N} 1: 160 \mathrm{~kg} \mathrm{ha}^{-1}$ & $375.91 \mathrm{de}$ & $303.91 \mathrm{~h}$ & $2.06 \mathrm{bc}$ & $1.34 \mathrm{fg}$ & $1.20 \mathrm{~cd}$ & $0.77 \mathrm{fg}$ & $3.26 \mathrm{bc}$ & $2.11 \mathrm{ef}$ & $0.612 b c$ & $0.448 \mathrm{de}$ \\
\hline $\mathrm{N} 2: 186 \mathrm{~kg} \mathrm{ha}^{-1}$ & $384.75 \mathrm{~cd}$ & $313.75 \mathrm{~g}$ & $2.15 \mathrm{ab}$ & $1.35 \mathrm{fg}$ & $1.25 \mathrm{bc}$ & $0.78 \mathrm{fg}$ & $3.40 \mathrm{ab}$ & $2.13 \mathrm{e}$ & $0.615 \mathrm{bc}$ & $0.455 \mathrm{de}$ \\
\hline N3: $220 \mathrm{~kg} \mathrm{ha}^{-1}$ & $389.75 \mathrm{c}$ & $315.75 \mathrm{~g}$ & $2.17 \mathrm{ab}$ & $1.38 \mathrm{ef}$ & $1.26 \mathrm{abc}$ & $0.80 \mathrm{f}$ & $3.43 \mathrm{a}$ & $2.18 \mathrm{e}$ & $0.619 \mathrm{abc}$ & $0.459 \mathrm{de}$ \\
\hline $\mathrm{N} 4: 267 \mathrm{~kg} \mathrm{ha}^{-1}$ & $423.69 \mathrm{~b}$ & $366.96 \mathrm{ef}$ & $2.21 \mathrm{a}$ & $1.51 \mathrm{de}$ & $1.29 \mathrm{ab}$ & $0.88 \mathrm{e}$ & $3.50 \mathrm{a}$ & $2.39 \mathrm{~d}$ & $0.636 \mathrm{ab}$ & $0.470 \mathrm{~d}$ \\
\hline N5: $293 \mathrm{~kg} \mathrm{ha}^{-1}$ & $436.42 \mathrm{a}$ & $374.86 \mathrm{e}$ & $2.24 \mathrm{a}$ & $1.59 \mathrm{~d}$ & $1.33 \mathrm{a}$ & $0.92 \mathrm{e}$ & $3.56 \mathrm{a}$ & $2.51 \mathrm{~d}$ & $0.646 \mathrm{a}$ & $0.474 \mathrm{~d}$ \\
\hline N6: $320 \mathrm{~kg} \mathrm{ha}^{-1}$ & $359.75 \mathrm{f}$ & $289.84 \mathrm{i}$ & $2.00 \mathrm{c}$ & $1.31 \mathrm{fg}$ & $1.16 \mathrm{~d}$ & $0.76 \mathrm{fg}$ & $3.15 c$ & $2.07 \mathrm{ef}$ & $0.601 \mathrm{c}$ & $0.443 \mathrm{e}$ \\
\hline \multicolumn{11}{|c|}{ Interactions between salinity levels and nitrogen levels } \\
\hline SL & \multicolumn{2}{|c|}{$1547.38^{* * *}$} & \multicolumn{2}{|c|}{$827.81^{* * *}$} & \multicolumn{2}{|c|}{$1192.67^{* * *}$} & \multicolumn{2}{|c|}{$1267.08^{* * *}$} & \multicolumn{2}{|c|}{$1026.30^{* * *}$} \\
\hline NL & \multicolumn{2}{|c|}{$198.80^{* * *}$} & \multicolumn{2}{|c|}{$11.31^{* * *}$} & \multicolumn{2}{|c|}{$16.70 * * *$} & \multicolumn{2}{|c|}{$17.43^{* * *}$} & \multicolumn{2}{|c|}{$4.63^{* *}$} \\
\hline $\mathrm{SL} \times \mathrm{NL}$ & \multicolumn{2}{|c|}{2.19 * } & \multicolumn{2}{|c|}{$0.82 \mathrm{~ns}$} & \multicolumn{2}{|c|}{$0.83 \mathrm{~ns}$} & \multicolumn{2}{|c|}{$1.05 \mathrm{~ns}$} & \multicolumn{2}{|c|}{$0.11 \mathrm{~ns}$} \\
\hline $\mathrm{CV}$ & \multicolumn{2}{|c|}{1.83} & \multicolumn{2}{|c|}{5.42} & \multicolumn{2}{|c|}{4.53} & \multicolumn{2}{|c|}{4.38} & \multicolumn{2}{|c|}{3.55} \\
\hline
\end{tabular}




\subsection{Antioxidant Enzyme Activities}

In this study, catalase activity (CAT) in maize plants was significantly affected by both SL and NL, while their interaction, SL $\times$ NL, showed a nonsignificant effect (Table 4). Across the control pots, and at $10 \mathrm{dS} \mathrm{m}^{-1}$ salinity, CAT activity in maize was decreased significantly with increased levels of $\mathrm{N}$. The lowest CAT activity of the respective antioxidant enzymes in maize was recorded at the $\mathrm{N} 5$ level of $\mathrm{N}$ (23.36 and $40.50 \mathrm{U} \mathrm{mg}^{-1}$ protein), whereas the highest CAT activity ( 30.11 and $48.45 \mathrm{U} \mathrm{mg}^{-1}$ protein) was found in the control (N0) treatment. The same behavior was observed in the peroxidase (POD) activity in maize plants, which was significantly affected by SL and NL, but their interaction, SL $\times \mathrm{NL}$, showed a nonsignificant impact on the POD activity (Table 4). Across the control pots, and at $10 \mathrm{dS} \mathrm{m}^{-1}$ salinity, the POD activity in maize plants was decreased significantly with an increase in the $\mathrm{N}$ level, except for the $\mathrm{N} 6\left(320 \mathrm{~kg} \mathrm{~N} \mathrm{ha}^{-1}\right)$ treatment. The lowest activity of POD in maize plants was recorded at the N5 level of $\mathrm{N}\left(293 \mathrm{~kg} \mathrm{~N} \mathrm{ha}^{-1}\right)$, which was $42.49 \mathrm{U} \mathrm{mg}^{-1}$ protein, whereas the highest activity was found in the control (N0) treatment (51.74 $\mathrm{U} \mathrm{mg}^{-1}$ protein) at a salinity level of $10 \mathrm{dS} \mathrm{m}^{-1}$.

Table 4. Effect of different of $\mathrm{N}$ application rates on antioxidant enzymes in maize plants under salt stress in pot conditions.

\begin{tabular}{|c|c|c|c|c|c|c|}
\hline \multirow[t]{2}{*}{ Nitrogen Levels } & \multicolumn{2}{|c|}{$\begin{array}{l}\text { Catalase Activity } \\
\text { (U mg }{ }^{-1} \text { Protein) }\end{array}$} & \multicolumn{2}{|c|}{$\begin{array}{l}\text { Peroxidase Activity } \\
\text { (U mg }{ }^{-1} \text { Protein) }\end{array}$} & \multicolumn{2}{|c|}{$\begin{array}{l}\text { Superoxide Dismutase activity } \\
\text { (U mg } \mathbf{~ m}^{-1} \text { Protein) }\end{array}$} \\
\hline & Control & $10 \mathrm{dS} \mathrm{m}^{-1}$ & Control & $10 \mathrm{dS} \mathrm{m}^{-1}$ & Control & $10 \mathrm{dS} \mathrm{m}^{-1}$ \\
\hline N0: control (untreated) & $30.11 \mathrm{e}$ & $48.45 \mathrm{a}$ & $32.91 \mathrm{e}$ & $51.74 \mathrm{a}$ & $35.93 \mathrm{~d}$ & $54.76 \mathrm{a}$ \\
\hline $\mathrm{N} 1: 160 \mathrm{~kg} \mathrm{ha}^{-1}$ & $28.65 \mathrm{efg}$ & $47.09 \mathrm{ab}$ & $30.50 \mathrm{efg}$ & $48.94 \mathrm{ab}$ & 33.03 ef & $52.24 \mathrm{ab}$ \\
\hline $\mathrm{N} 2: 186 \mathrm{~kg} \mathrm{ha}^{-1}$ & $28.03 \mathrm{efg}$ & $45.39 \mathrm{abc}$ & $29.67 \mathrm{fg}$ & $47.83 \mathrm{bc}$ & 32.88 ef & $51.91 \mathrm{~b}$ \\
\hline N3: $220 \mathrm{~kg} \mathrm{ha}^{-1}$ & $26.43 \mathrm{fgh}$ & $44.84 \mathrm{bc}$ & $28.32 \mathrm{fgh}$ & $47.23 \mathrm{bc}$ & $31.18 \mathrm{fg}$ & $50.08 \mathrm{~b}$ \\
\hline $\mathrm{N} 4: 267 \mathrm{~kg} \mathrm{ha}^{-1}$ & $25.35 \mathrm{gh}$ & $42.76 \mathrm{~cd}$ & $27.63 \mathrm{gh}$ & $44.78 \mathrm{~cd}$ & $29.53 \mathrm{gh}$ & $46.61 \mathrm{c}$ \\
\hline N5: $293 \mathrm{~kg} \mathrm{ha}^{-1}$ & $23.36 \mathrm{~h}$ & $40.50 \mathrm{~d}$ & $25.46 \mathrm{~h}$ & $42.49 \mathrm{~d}$ & $27.22 \mathrm{~h}$ & $43.90 \mathrm{c}$ \\
\hline N6: $320 \mathrm{~kg} \mathrm{ha}^{-1}$ & 28.86 ef & $46.04 \mathrm{abc}$ & $31.28 \mathrm{ef}$ & $49.44 \mathrm{ab}$ & 33.98 de & $52.70 \mathrm{ab}$ \\
\hline \multicolumn{7}{|c|}{ Interactions between salinity levels and nitrogen levels } \\
\hline SL & \multicolumn{2}{|c|}{$768.89 * * *$} & \multicolumn{2}{|c|}{$939.66^{* * *}$} & \multicolumn{2}{|c|}{$1281.69^{* * *}$} \\
\hline NL & \multicolumn{2}{|c|}{$8.65^{* * *}$} & \multicolumn{2}{|c|}{$12.55^{* * *}$} & \multicolumn{2}{|c|}{$24.33 * * *$} \\
\hline $\mathrm{SL} \times \mathrm{NL}$ & \multicolumn{2}{|c|}{$0.13 \mathrm{~ns}$} & \multicolumn{2}{|c|}{$0.23 \mathrm{~ns}$} & \multicolumn{2}{|c|}{$0.58 \mathrm{~ns}$} \\
\hline $\mathrm{CV}$ & \multicolumn{2}{|c|}{6.63} & \multicolumn{2}{|c|}{5.75} & \multicolumn{2}{|c|}{4.66} \\
\hline
\end{tabular}

Values are means of four replicates. For each parameter, under each column, values sharing different letters differ significantly from each other at $p<0.05$. NS: nonsignificant, ${ }^{* * *}: p<0.001$, SL: salt level, NL: nitrogen level. Degrees of freedom (df) for SL: 1, NL: 6 , and SL $\times$ NL: 6 .

The results regarding the superoxide dismutase (SOD) activity depict that both SL and NL had a significant effect, while their interaction showed a nonsignificant effect on the SOD activity (Table 4 ). In both types of control and $10 \mathrm{dS} \mathrm{m}^{-1}$ saline pots, a significant reduction was recorded in the SOD activity at the N5 $\left(293 \mathrm{~kg} \mathrm{~N} \mathrm{ha}^{-1}\right)$ treatment, and the highest activity was observed in the control (N0) treatment.

\subsection{Nitrogen Use Efficiencies of Maize Plants}

The results regarding the $\mathrm{N}$ harvest index (NHI) reveal that the NHI was markedly affected by both SL and NL, but their interaction (SL $\times$ NL) showed nonsignificant results (Table 5). In all control pots, an increase in the NHI was observed up to the N5 $\left(293 \mathrm{~kg} \mathrm{~N} \mathrm{ha}^{-1}\right.$ ) level, and in the case of pots of $10 \mathrm{dS} \mathrm{m}^{-1}$ salinity, the same N level (N5) was found, but a nonsignificant increase in the NHI was observed at $\mathrm{N}$ levels of N1, N2, $\mathrm{N} 3$, and N6, whereas the lowest NHI (10.03\%) was recorded in the control (N0) treatment. 
Table 5. Effect of different $\mathrm{N}$ application rates on $\mathrm{N}$ harvest index and various $\mathrm{N}$ efficiencies of maize plants under salt stress in pot conditions.

\begin{tabular}{|c|c|c|c|c|c|c|c|c|c|c|}
\hline \multirow{2}{*}{ Nitrogen Levels } & \multicolumn{2}{|c|}{ N Harvest Index (\%) } & \multicolumn{2}{|c|}{ NUE $\left(g\right.$ DM g $\left.g^{-1} N\right)$} & \multicolumn{2}{|c|}{ NYE $\left(g^{D M} g^{-1} N\right)$} & \multicolumn{2}{|c|}{$\operatorname{PNE}\left(\mathrm{g} \mathrm{DM} \mathrm{g}^{-1} \mathrm{~N}\right)$} & \multicolumn{2}{|c|}{ PNUE (g DM g $\left.{ }^{-1} \mathrm{~N}\right)$} \\
\hline & Control & $10 \mathrm{dS} \mathrm{m}^{-1}$ & Control & $10 \mathrm{dS} \mathrm{m}^{-1}$ & Control & $10 \mathrm{dS} \mathrm{m}^{-1}$ & Control & $10 \mathrm{dS} \mathrm{m}^{-1}$ & Control & $10 \mathrm{dS} \mathrm{m}^{-1}$ \\
\hline $\begin{array}{l}\text { N0: control } \\
\text { (untreated) }\end{array}$ & $13.92 \mathrm{e}$ & $10.03 \mathrm{f}$ & - & - & - & - & - & - & 6.10 ef & $4.49 \mathrm{~g}$ \\
\hline $\mathrm{N} 1: 160 \mathrm{~kg} \mathrm{ha}^{-1}$ & $27.49 c$ & $22.51 \mathrm{~d}$ & $1.71 \mathrm{e}$ & $1.37 \mathrm{f}$ & $8.78 \mathrm{~d}$ & $5.20 \mathrm{~g}$ & $9.11 \mathrm{~cd}$ & $5.61 \mathrm{e}$ & $8.35 \mathrm{~cd}$ & $5.60 \mathrm{f}$ \\
\hline $\mathrm{N} 2: 186 \mathrm{~kg} \mathrm{ha}^{-1}$ & $29.28 \mathrm{bc}$ & $22.53 \mathrm{~d}$ & $1.85 \mathrm{~cd}$ & $1.44 \mathrm{f}$ & $9.49 \mathrm{~cd}$ & $5.71 \mathrm{fg}$ & $9.50 \mathrm{c}$ & $5.80 \mathrm{e}$ & $8.98 \mathrm{bc}$ & $6.56 \mathrm{e}$ \\
\hline N3: $220 \mathrm{~kg} \mathrm{ha}^{-1}$ & $31.39 \mathrm{~b}$ & $24.21 \mathrm{~d}$ & $1.91 \mathrm{bc}$ & $1.48 \mathrm{f}$ & $10.34 \mathrm{~b}$ & $6.01 \mathrm{f}$ & $9.61 \mathrm{bc}$ & $5.90 \mathrm{e}$ & $9.49 \mathrm{~b}$ & $6.78 \mathrm{e}$ \\
\hline $\mathrm{N} 4: 267 \mathrm{~kg} \mathrm{ha}^{-1}$ & $36.02 \mathrm{a}$ & $29.63 \mathrm{bc}$ & $2.03 \mathrm{ab}$ & $1.74 \mathrm{de}$ & $11.79 \mathrm{a}$ & $7.36 \mathrm{e}$ & $10.21 \mathrm{~b}$ & $6.07 \mathrm{e}$ & $11.73 \mathrm{a}$ & $8.06 \mathrm{~d}$ \\
\hline N5: $293 \mathrm{~kg} \mathrm{ha}^{-1}$ & $37.55 \mathrm{a}$ & $31.28 \mathrm{~b}$ & $2.10 \mathrm{a}$ & 1.81 cde & $12.16 \mathrm{a}$ & $7.74 \mathrm{e}$ & $11.83 \mathrm{a}$ & $8.66 \mathrm{~d}$ & $11.96 \mathrm{a}$ & $8.52 \mathrm{~cd}$ \\
\hline \multirow[t]{2}{*}{ N6: $320 \mathrm{~kg} \mathrm{ha}^{-1}$} & $29.78 \mathrm{bc}$ & $22.57 \mathrm{~d}$ & $1.85 \mathrm{~cd}$ & $1.46 \mathrm{f}$ & $9.63 \mathrm{bc}$ & $5.79 \mathrm{bc}$ & $9.23 \mathrm{~cd}$ & $5.66 \mathrm{e}$ & $8.40 \mathrm{~cd}$ & $6.58 \mathrm{e}$ \\
\hline & & & & ractions bet & salinity lev & nitrogen le & & & & \\
\hline SL & \multicolumn{2}{|c|}{$168.83^{* * *}$} & \multicolumn{2}{|c|}{$183.54^{* * *}$} & \multicolumn{2}{|c|}{$771.59^{* * *}$} & \multicolumn{2}{|c|}{$661.64^{* * * *}$} & \multicolumn{2}{|c|}{$396.58^{* * *}$} \\
\hline NL & \multicolumn{2}{|c|}{$137.41^{* * *}$} & \multicolumn{2}{|c|}{$24.07^{* * *}$} & \multicolumn{2}{|c|}{$43.08^{* * *}$} & \multicolumn{2}{|c|}{$39.58^{* * *}$} & \multicolumn{2}{|c|}{$92.34^{* * *}$} \\
\hline $\mathrm{SL} \times \mathrm{NL}$ & \multicolumn{2}{|c|}{$0.99 \mathrm{~ns}$} & \multicolumn{2}{|c|}{$0.84 \mathrm{~ns}$} & \multicolumn{2}{|c|}{$1.10 \mathrm{~ns}$} & \multicolumn{2}{|c|}{$0.85 \mathrm{~ns}$} & \multicolumn{2}{|c|}{$6.43^{* * *}$} \\
\hline $\mathrm{CV}$ & \multicolumn{2}{|c|}{6.68} & \multicolumn{2}{|c|}{5.29} & \multicolumn{2}{|c|}{6.08} & \multicolumn{2}{|c|}{6.03} & \multicolumn{2}{|c|}{6.22} \\
\hline
\end{tabular}

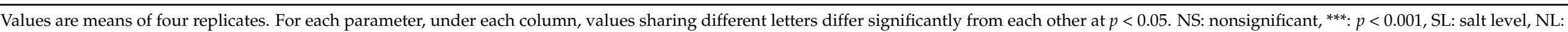

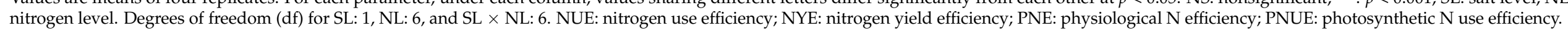


The data regarding the nitrogen use efficiency (NUE) reveal that the NUE was significantly affected by SL and NL; however, their interaction effect was found to be nonsignificant for the NUE (Table 5). The highest NUE across control pots was recorded in the N5 $\left(293 \mathrm{~kg} \mathrm{~N} \mathrm{ha}^{-1}\right)$ treatment, while N1 depicted the lowest NUE $\left(1.71 \mathrm{~g} \mathrm{DM} \mathrm{g}^{-1} \mathrm{~N}\right)$ among all $\mathrm{N}$ treatments. However, at a salinity level of $10 \mathrm{dS} \mathrm{m}^{-1}$, a nonsignificant increase in the NUE was observed with $\mathrm{N}$ fertilization, except for the N5 and N4 treatments that showed a significantly higher NUE $\left(1.81 \mathrm{~g} \mathrm{DM} \mathrm{g}^{-1} \mathrm{~N}\right)$ in maize plants.

The results of the nitrogen yield efficiency (NYE) show that the effect of both SL and NL was significant, while the effect of their interaction was observed to be nonsignificant for the NYE (Table 5). The highest NYE was recorded in N5 (293 kg N ha $\left.{ }^{-1}\right)$ followed by the N4 and N3 treatments, while N1 returned the lowest NYE $\left(8.78 \mathrm{~g} \mathrm{DM} \mathrm{g}^{-1} \mathrm{~N}\right)$ among all $\mathrm{N}$ treatments. Similarly, at $10 \mathrm{dS} \mathrm{m}^{-1}$ salinity, a significant increase in the NYE was also found with $\mathrm{N}$ fertilization at the $\mathrm{N} 5\left(7.74 \mathrm{~g} \mathrm{DM} \mathrm{g}^{-1} \mathrm{~N}\right)$ and $\mathrm{N} 4\left(7.36 \mathrm{~g} \mathrm{DM} \mathrm{g}^{-1} \mathrm{~N}\right)$ treatments, resulting in a significantly higher NYE in maize plants.

The results of the physiological $\mathrm{N}$ efficiency (PNE) depict that both SL and NL had a significant effect on the PNE in maize plants, while the interaction of both salt and $\mathrm{N}$ levels did not reveal any significant effect on the PNE of the plants (Table 5). Both saline $\left(10 \mathrm{dS} \mathrm{m}{ }^{-1}\right)$ and control soil pots elucidated that highest PNE (8.66 and $11.83 \mathrm{~g} \mathrm{DM} \mathrm{g}^{-1}$, respectively), which was observed at the $\mathrm{N} 5$ (293 $\mathrm{kg} \mathrm{N} \mathrm{ha}^{-1}$ ) level of $\mathrm{N}$, whereas $\mathrm{N} 1$ showed the lowest value of the PNE in maize plants.

The results of the photosynthetic $\mathrm{N}$ use efficiency (PNUE) show that SL, NL, and their interaction (SL $\times$ NL) had a significant effect on the PNUE in maize plants (Table 5). In the control and $10 \mathrm{dS} \mathrm{m} \mathrm{m}^{-1}$ pots, the highest value of the PNUE was recorded up to $8.52 \mathrm{~g} \mathrm{DM} \mathrm{g}^{-1}$ due to application of $\mathrm{N} 5$ and N4, respectively, with respect to the control (N0) treatment, where no $\mathrm{N}$ was applied.

\section{Discussion}

Among the biotic stresses, salinity always exerts a significant effect on the growth and yield of crop plants by inducing changes in metabolic activities, such as a specific ion effect, decreased nutrient intake, reduced water potential and chlorophyll contents, and increased antioxidant activities [54-56]. Nitrogen can enhance plants adaptation to tolerate salinity stress, since $\mathrm{N}$ is a key growth essential nutrient due to its significant contribution to the synthesis of proteins, polyamines, amino acids, and amides $[9,57,58]$.

In this study, the rate of $\mathrm{N}$ fertilization was an important determinant of plant physiological and biochemical responses under salinity. Importantly, an improvement in plant physiological and biochemical attributes was very evident when plants were fed with nitrogen level N5 (293 kg N ha ${ }^{-1}$ ); however, N6 (320 kg N ha ${ }^{-1}$ ) led to a decrease in the plant physiological and biochemical parameters because of the nitrogen toxicity in the plants, as the most stable reactive oxygen species (ROS) and hydrogen peroxide $\left(\mathrm{H}_{2} \mathrm{O}_{2}\right)$ generation can contribute to oxidative stress by disrupting the membrane permeability and increasing lipid peroxidation $[59,60]$.

Contrariwise, electrolyte leakage was significantly reduced in stressed plants following $\mathrm{N}$ fertilization, and these valuable effects are attributed to the positive role of the adequate $\mathrm{N}$ supply on membrane stability that, in turn, aided $\mathrm{Na}$ exclusion and, consequently, improved the water supply across different plant compartments. Additionally, the presence of sufficient $\mathrm{N}$ improved the plant metabolic functions that are best reflected by the increase in $\mathrm{CO}_{2}$ assimilation during photosynthesis, and the improvement in the chlorophyll and carotenoid contents [61,62].

Plants express both enzymatic and nonenzymatic antioxidant activities to thwart stress-induced oxidative damage [63]. In this study, the N5 treatment prompted a decrease in the antioxidant enzymes' activity (CAT, POD, and SOD), with concomitant low proline and malondialdehyde (MDA) contents, which might be associated with the level of salinity exposure. With optimum nitrogen nutrition, the adverse effects of salinity in maize plants were relegated, as evident by the decrease in the MDA concentration. In addition, the 
proline contents and antioxidant enzyme activities were regulated in order to limit the production of ROS, eventually invoking stronger $\mathrm{N}$-mediated plant defense against salinity stress $[64,65]$.

Similarly, Nadian et al. [16] also noted that urea application at three different $\mathrm{N}$ rates alleviated the salinity-related negative effects on sugarcane. Although the minimization of salinity-related detrimental effects was associated with the overapplication of $\mathrm{N}$ fertilizers, it positively affected the leaf proline content and upregulated $\mathrm{K}$ metabolism as a marker of stress adaptation.

The extensive use of $\mathrm{N}$ fertilizers and the decline in $\mathrm{N}$ utilization efficiencies have caused widespread concern across agroecosystems [66,67]. Our current work proved that maize plants with an optimal $\mathrm{N}$ supply (N5) could improve various nitrogen use efficiency attributes, including NUE, NYE, PNE, PNUE, and NHI. These results also illustrate the higher antagonistic interaction of $\mathrm{N}$ with $\mathrm{Na}$ and $\mathrm{Cl}$ that might have improved the assimilatory function of the nitrogenous biochemical machinery, leading to an increase in the nitrogen yield efficiency, physiological nitrogen efficiency, photosynthetic nitrogen use efficiency, and nitrogen harvest index. This indicates that the increased concentration of $\mathrm{N}$ balanced the photosynthetic system under salinity stress through assimilation of carbon dioxide to increase stomatal conductivity in the $C$ plant skeleton $[25,68,69]$. Similar results were also reported by Song et al. [70], attributing improved NUE to optimal N supply in oat plant under salinity stress.

\section{Conclusions}

The results of this study show that the interaction between salinity and $\mathrm{N}$ application improved all biochemical and physiological characteristics of maize plants at $10 \mathrm{dS} \mathrm{m}^{-1}$ salt stress. Higher $\mathrm{N}$ content $\left(293 \mathrm{~kg} \mathrm{~N} \mathrm{ha}^{-1}\right)$ in the form of urea was found to be effective in reducing the deleterious effects of salt $(\mathrm{NaCl})$ on biochemical and physiological properties as well as antioxidant enzyme activity and $\mathrm{N}$ use efficiency of maize plants. In the present study, it is evident that increased $\mathrm{N}$ concentration up to $293 \mathrm{~kg} \mathrm{~N}^{-1}$ under salt stress can increase crop yield by enhancing tolerance mechanisms and regulating plant metabolism under salt stress. Although the main limitation of this study is that it was conducted in pots under greenhouse conditions and these treatments were not tested under field conditions, this study still provides baseline data which could be useful to conduct this study under field conditions with the same treatments in different ecological zones of Pakistan to establish the real authenticity of the results.

Author Contributions: S.A.J., M.S.A., S.M.S. and M.A. conducted the methodology, formal analysis, data curation, software, and writing-review and editing. R.K., T.H.F., M.I.H. and A.S. reviewed the draft, and helped in the correction and revision. All authors have read and agreed to the published version of the manuscript.

Funding: This research study did not receive any external funding.

Institutional Review Board Statement: Not applicable.

Informed Consent Statement: Not applicable.

Data Availability Statement: The data mentioned in this study are available on request from the corresponding author.

Availability of Data and Materials: All the available data are presented in the manuscript.

Ethics Approval and Consent to Participate: Not Applicable.

Conflicts of Interest: The authors declare no conflict of interest. 


\section{References}

1. Schwabele, K.A.; Iddo, K.; Knap, K.C. Drain water management for salinity mitigation in irrigated agriculture. Am. J. Agric. Econ. 2006, 88, 133-140. [CrossRef]

2. Bray, E.A.; Bailey-Serres, J.; Weretilnyk, E. Responses to abiotic stresses. In Biochemistry and Molecular Biology of Plants; Buchanan, B.B., Gruissem, W., Jones, R.L., Eds.; American Society of Plant Biologists: Rockville, MD, USA, 2000; pp. $1158-1203$.

3. Shrivastava, P.; Kumar, R. Soil salinity: A serious environmental issue and plant growth promoting bacteria as one of the tools for its alleviation. Saudi. J. Biol. Sci. 2015, 22, 123-131. [CrossRef]

4. Wei, C.; Li, F.; Yang, P.; Ren, S.; Wang, S.; Wang, Y.; Xu, Z.; Xu, Y.; Wei, R.; Zhang, Y. Effects of irrigation water salinity on soil properties, $\mathrm{N}_{2} \mathrm{O}$ emission and yield of spring maize under mulched drip irrigation. Water 2019, 11, 1548. [CrossRef]

5. Feng, G.X.; Zhang, Z.Y.; Wan, C.Y.; Lu, P.R.; Bakour, A. Effects of saline water irrigation on soil salinity and yield of summer maize (Zea mays L.) in subsurface drainage system. Agric. Water Manag. 2017, 193, 205-213. [CrossRef]

6. Abideen, Z.; Ansari, R.; Gul, B.; Khan, M.A. Theplace of halophytes in Pakistan's biofuel industry. Biofuels 2012, 3, 211-220. [CrossRef]

7. Rubio, J.S.; Garcia-Sanchez, F.; Rubio, F.; Martinez, V. Yield, blossom-end rot incidence and fruit quality in pepper plants under moderate salinity are affected by $\mathrm{K}^{+}$and $\mathrm{Ca}^{2+}$ fertilization. Sci. Horti. 2009, 119, 79-87. [CrossRef]

8. Xiong, L.; Schumaker, K.S.; Zhu, J.K. Cell signaling during cold, drought, and salt stress. Plant Cell 2002, 14, S165-S183. [CrossRef] [PubMed]

9. Zaki, S.S. Effect of compost and nitrogen fertilization on yield and nutrients uptake of rice crop under saline soil. Mod. Chem. Appl. 2016, 4, 183. [CrossRef]

10. Gimeno, V.; Syvertsen, J.P.; Nieves, M.; Simón, I.; Martínez, V.; García-Sánchez, F. Additional nitrogen fertilization affects salt tolerance of lemon trees on different rootstocks. Sci. Horti. 2009, 121, 298-305. [CrossRef]

11. Hernandez, J.A.; Almansa, M.S. Short term effects of salt stress on antioxidant systems and leaf water relations of pea leaves. Physiol. Plant. 2002, 115, 251-257. [CrossRef] [PubMed]

12. El-Shintinawy, F.; El-Ansary, A. Differential Effect effect of $\mathrm{Cd}^{2+}$ and $\mathrm{Ni}^{2+}$ on amino acid metabolism in soybean seedlings. Biol. Plant. 2000, 43, 79-84. [CrossRef]

13. Muradoglu, F.; Gundogdu, M.; Ercisli, S.; Encu, T.; Balta, F.; Jaafar, H.Z.; Zia-Ul-Haq, M. Cadmium toxicity affects chlorophyll $a$ and $b$ content, antioxidant enzyme activities and mineral nutrient accumulation in strawberry. Biol. Res. 2015, 48, 1-7. [CrossRef]

14. Nathawat, N.S.; Kuhad, M.S.; Goswami, C.L.; Patel, A.L.; Kumar, R. Nitrogen-metabolizing enzymes: Effect of nitrogen sources and saline irrigation. J. Plant Nutr. 2005, 28, 1089-1101. [CrossRef]

15. Parida, A.K.; Das, A.B. Effects of $\mathrm{NaCl}$ stress on nitrogen and phosphorous metabolism in a true mangrove Bruguiera parviflora grown under hydroponic culture. J. Plant Physiol. 2004, 161, 921-928. [CrossRef] [PubMed]

16. Nadian, H.; Nateghzadwh, B.; Jafari, S. Effect of salinity and nitrogen fertilizers on some quantity and quality parameters of sugarcane (Saccharum sp.). J. Food Agric. Environ. 2012, 10, 470-474.

17. Khan, H.R.; Ashraf, M.; Shahzad, S.M.; Aziz, A.; Piracha, M.A.; Siddiqui, A.R. Adequate regulation of plant nutrients for improving cotton adaptability to salinity stress. J. Appl. Agric. Biotechnol. 2016, 1, 47-56.

18. Guo, J.S.; Zhou, Q.; Li, X.J.; Yu, B.J.; Luo, Q.Y. Enhancing $\mathrm{NO}_{3}{ }^{-}$supply confers $\mathrm{NaCl}$ tolerance by adjusting $\mathrm{Cl}^{-}$uptake and transport in G. max and G. soja. J. Soil Sci. Plant Nutr. 2017, 17, 194-204. [CrossRef]

19. Heidari, A.; Toorchi, M.; Bandehagh, A.; Shakiba, M. Effect of $\mathrm{NaCl}$ stress on growth, water relations, organic and inorganic osmolytes accumulation in sunflower (Helianthus annuus L.) lines. Univ. J. Environ. Res. Technol. 2011, 3, 351-362.

20. Fayez, K.A.; Bazaid, S.A. Improving drought and salinity tolerance in barley by application of salicylic acid and potassium nitrate. J. Saudi Soc. Agric. Sci. 2014, 13, 45-55. [CrossRef]

21. Akram, M.S.; Ashraf, M. Alleviation of adverse effects of salt stress on sunflower (Helianthus annuus L.) by exogenous application of potassium nitrate. J. Appl. Bot. Food Qual. 2009, 83, 19-27.

22. Bahmanzadegan, M.J.; Aboutalebi, A. Effect of ammonium nitrate on dry weight, sodium and potassium levels of French marigold (Tageta patula) in salinity stress condition. J. Nov. Appl. Sci. 2013, 2S, 835-840.

23. Iglesias, D.J.; Levy, Y.; Gomez-Cadenas, A.; Tadeo, F.R.; Primo-Millo, E.; Talon, M. Nitrate improves growth in salt-stressed citrus seedlings through effects on photosynthetic activity and chloride accumulation. Tree Physiol. 2004, 24, 1027-1034. [CrossRef]

24. Rais, I.; Masood, A.; Inam, A.; Khan, N. Sulfur and nitrogen coordinately improve photosynthetic efficiency, growth and proline accumulation in two cultivars of mustard under salt stress. J. Plant Biochem. Physiol. 2013, 1, 101. [CrossRef]

25. Bybordi, A. Effects of salinity on yield and component characters in canola (Brassica napus L.) cultivars. Not. Sci. Biol. 2010, 2, 81-83. [CrossRef]

26. Nhung, P.T.H.; Hanh, T.T.; Bertin, P.; Cuong, P.V. Effect of inorganic nitrogen forms and concentrations on growth of rice genotypes under severe saline condition. Viet. J. Agric. Sci. 2017, 15, 189-197.

27. Kabir, M.E.; Hamid, A.; Haque, M.M.; Nawata, E.; Karim, M.A. Effect of nitrogen fertilizer on salinity tolerance of mungbean (Vigna radiata L. Wilczek). Jap. J. Trop. Agri. 2005, 49, 119-125.

28. Tabatabaei, S.J. Effects of salinity and $\mathrm{N}$ on the growth, photosynthesis and $\mathrm{N}$ status of olive (Olea europaea L.) trees. Sci. Horti. 2006, 108, 432-438. [CrossRef]

29. Bouyoucos, G.J. Hydrometer method improved for making particle size analyses of soils. Agron. J. 1962, 54, 464-465. [CrossRef]

30. Jackson, M.L. Soil Chemical Analysis; Prentice Hall: Englewood Cliffs, NJ, USA, 1967. 
31. Walkley, A.J.; Black, I.A. Estimation of soil organic carbon by the chromic acid titration method. Soil Sci. 1934, 37, 29-38. [CrossRef]

32. Bremner, J.M.; Tabatabai, M.A. Use of an ammonia electrode for determination of ammonium in Kjeldahl analysis of soils. Comm. Soil Sci. Plant Anal. 1972, 3, 159-165. [CrossRef]

33. Olsen, S.R.; Cole, C.V.; Watanabe, F.S.; Dean, L.A. Estimation of Available Phosphorus in Soils by Extraction with Sodium Bicarbonate; Banderis, A.D., Barter, D.H., Anderson, K., Eds.; Circular 939; U.S. Department of Agriculture: Washington, DC, USA, 1954; pp. 1-19.

34. Hanway, J.J.; Heidel, H. Soil analysis methods as used in Iowa state college, Soil Testing Laboratory. Iowa Agric. 1952, 54, 1-31.

35. Brady, N.C.; Weil, R.R.; Weil, R.R. The Nature and Properties of Soils, 12th ed.; Prentice Hall Publishers: London, UK, $1990 ;$ p. 740.

36. Turner, N.C. Techniques and experimental approaches for the measurement of plant water status. Plant Soil 1981, 58, 339-366. [CrossRef]

37. Lutts, S.; Kinet, J.M.; Bouharmont, J. NaCl induced senescence in leaves of rice (Oryza sativa L.) cultivars differing in salinity resistance. Ann. Bot. 1996, 78, 389-398. [CrossRef]

38. Singh, A.; Kumar, J.; Kumar, P. Effects of plant growth regulators and sucrose on postharvest physiology, membrane stability and vase life of cut spikes of gladiolus. Plant Growth Reg. 2008, 55, 221. [CrossRef]

39. Shabala, S.N.; Shabala, S.I.; Martynenko, A.I.; Babourina, O.; Newman, I.A. Salinity effect on bioelectric activity, growth, Na ${ }^{+}$ accumulation and chlorophyll fluorescence of maize leaves: A comparative survey and prospects for screening. Fun. Plant Biol. 1998, 25, 609-616. [CrossRef]

40. Lichtenthaler, H.K.; Hak, R.; Rinderle, U. The chlorophyll fluorescence ratio F690/F730 in leaves of different chlorophyll content. Photosynth. Res. 1990, 25, 295-298. [CrossRef] [PubMed]

41. Bates, L.S.; Waldren, R.P.; Teare, I.D. Rapid determination of free proline for water stress studies. Plant Soil 1973, 39, 205-207. [CrossRef]

42. Heath, R.L.; Packer, L. Photoperoxidation in isolated chloroplasts: I. Kinetics and stoichiometry of fatty acid peroxidation. Arch. Biochem. Biophys. 1968, 125, 189-198. [CrossRef]

43. Mukherjee, S.P.; Choudhuri, M.A. Implications of water stress-induced changes in the levels of endogenous ascorbic acid and hydrogen peroxide in vigna seedlings. Physiol. Plant. 1983, 58, 166-170. [CrossRef]

44. Aebi, H. Catalase in vitro. In Methods in Enzymology; Academic Press: Cambridge, MA, USA, 1984; Volume 105, pp. 121-126. [CrossRef]

45. Maehly, A.; Chance, B. Catalases and peroxidases. Methods Biochem. Anal. 1954, 1, 357-424. [PubMed]

46. Dhindsa, R.S.; Plumb-Dhindsa, P.; Thorpe, T.A. Leaf senescence: Correlated with increased levels of membrane permeability and lipid peroxidation, and decreased levels of superoxide dismutase and catalase. J. Exp. Bot. 1981, 32, 93-101. [CrossRef]

47. Ye, Q.; Zhang, H.; Wei, H.; Zhang, Y.; Wang, B.; Xia, K.; Huo, Z.; Dai, Q.; Xu, K. Effects of nitrogen fertilizer on nitrogen use efficiency and yield of rice under different soil conditions. Front. Agric. China 2007, 1, 30-36. [CrossRef]

48. Moll, R.H.; Kamprath, E.J.; Jackson, W.A. Analysis and interpretation of factors which contribute to efficiency of nitrogen utilization ${ }^{1}$. Agron. J. 1982, 74, 562-564. [CrossRef]

49. Fageria, N.K.; Baligar, V.C. Enhancing nitrogen use efficiency in crop plants. Adv. Agron. 2005, 88, 97-185.

50. Dawson, J.C.; Huggins, D.R.; Jones, S.S. Characterizing nitrogen use efficiency in natural and agricultural ecosystems to improve the performance of cereal crops in low input and organic agricultural systems. Field Crop. Res. 2008, 107, 89-101. [CrossRef]

51. Poorter, H.; Evans, J.R. Photosynthetic nitrogen use efficiency of species that differ inherently in specific leaf area. Oecologia 1998, 116, 26-37. [CrossRef]

52. Smith, B.D.; Srivastava, R. Physical Sciences Data, Thermodynamic Data for Pure Compounds, Part A: Hydrocarbons and Ketones, 25th ed.; Elsevier: New York, NY, USA, 1986.

53. Steel, R.G.; Torrie, J.H.; Dickey, D.A. Principles and Procedures of Statistics: A Biological Approach, 3rd ed.; McGraw-Hill. Co., Inc.: New York, NY, USA, 1997.

54. Ahmad, P.; Azooz, M.M.; Prasad, M.N.V. Ecophysiology and responses of plants under salt stress. Spring. Sci. Busin. Med. 2013, 512. [CrossRef]

55. Khan, N.A.; Khan, M.I.R.; Asgher, M.; Fatma, M.; Masood, A.; Syeed, S. Salinity tolerance in plants: Revisiting the role of sulfur metabolites. J. Plant Biochem. Physiol. 2014, 2, 2. [CrossRef]

56. Acosta-Motos, J.R.; Ortuño, M.F.; Bernal-Vicente, A.; Diaz-Vivancos, P.; Sanchez-Blanco, M.J.; Hernandez, J.A. Plant responses to salt stress: Adaptive mechanisms. Agronomy 2017, 7, 18. [CrossRef]

57. Kamel, M. Improving the tolerance of Vicia faba against environmental salinity resulted from the irrigation with sea water by using $\mathrm{KNO}_{3}$ and $\left(\mathrm{NH}_{4}\right)_{2} \mathrm{SO}_{4}$ as chemical osmo-regulators. Acta Biol. Colomb. 2012, 17, 295-308.

58. Arghavani, M.A.; Zaeimzadeh, A.; Savadkoohi, S.; Samiei, L. Salinity tolerance of Kentucky bluegrass as affected by nitrogen fertilization. J. Agric. Sci. Technol. 2017, 19, 173-183.

59. Upchurch, R.G. Fatty acid unsaturation, mobilization, and regulation in the response of plants to stress. Biotech. Lett. 2008, 30, 967-977. [CrossRef]

60. Habib, N.; Ali, Q.; Ali, S.; Javed, M.T.; Haider, M.Z.; Perveen, R.; Shahid, M.R.; Rizwan, M.; Abdel-Daim, M.M.; Elkelish, A. Use of Nitric oxide and hydrogen peroxide for better yield of wheat (Triticum aestivum L.) under water deficit conditions: Growth, osmoregulation, and antioxidative defense mechanism. Plants 2020, 9, 285. [CrossRef] 
61. Akram, M.; Ashraf, M.Y.; Ahmad, R.; Waraich, E.A.; Iqbal, J.; Mohsan, M. Screening for salt tolerance in maize (Zea mays L.) hybrids at an early seedling stage. Pak. J. Bot. 2010, 42, 141-154.

62. Shah, S.H.; Houborg, R.; McCabe, M.F. Response of chlorophyll, carotenoid and SPAD-502 measurement to salinity and nutrient stress in wheat (Triticum aestivum L.). Agron. J. 2017, 7, 61. [CrossRef]

63. Ghalati, R.E.; Shamili, M.; Homaei, A. Effect of putrescine on biochemical and physiological characteristics of guava (Psidium guajava L.) seedlings under salt stress. Sci. Horti. 2020, 261, 108961. [CrossRef]

64. Singh, M.; Singh, V.P.; Prasad, S.M. Nitrogen alleviates salinity toxicity in Solanum lycopersicum seedlings by regulating ROS homeostasis. Plant Physiol. Biochem. 2019, 141, 466-476. [CrossRef]

65. Sikder, R.K.; Wang, X.; Zhang, H.; Gui, H.; Dong, Q.; Jin, D.; Song, M. Nitrogen enhances salt tolerance by modulating the antioxidant defense system and osmoregulation substance content in Gossypium hirsutum. Plants 2020, 9, 450. [CrossRef]

66. Liu, X.; Zhang, Y.; Han, W.; Tang, A.; Shen, J.; Cui, Z.; Vitousek, P.; Erisman, J.W.; Goulding, K.; Fangmeier, A. Enhanced nitrogen deposition over China. Nature 2013, 494, 459-462. [CrossRef] [PubMed]

67. Zhang, W.F.; Dou, Z.X.; He, P.; Ju, X.T.; Powlson, D.; Chadwick, D.; Norse, D.; Liu, Y.; Chen, X.P. New technologies reduce greenhouse gas emissions from nitrogenous fertilizer in China. Proc. Natl. Acad. Sci. USA 2013, 110, 8375-8380. [CrossRef] [PubMed]

68. Flores, H.; Atkinson, A.; Kawaguchi, S.; Krafft, B.A.; Milinevsky, G.; Nicol, S.; Werner, T. Impact of climate change on Antarctic krill. Mar. Ecol. Prog. Ser. 2012, 458, 1-19. [CrossRef]

69. Hnilickova, H.; Kraus, K.; Vachova, P.; Hnilicka, F. Salinity stress affects photosynthesis, malondialdehyde formation, and proline content in Portulaca oleracea L. Plants 2021, 10, 845. [CrossRef]

70. Song, X.; Zhou, G.; Ma, B.L.; Wu, W.; Ahmad, I.; Zhu, G.L.; Yan, W.Y.; Jiao, X. Nitrogen application improved photosynthetic productivity, chlorophyll fluorescence, yield and yield components of two oat genotypes under saline conditions. Agronomy 2019, 9, 115. [CrossRef] 